\title{
CORRESPONDENCE
}

The Managerial Revolution

J. D. Banks, M.A.; F. G. Hattersley, M.B., and

G. N. Cash, M.B.; A. P. Barter, M.B.......44

The Ward Sister

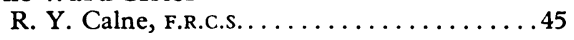

Brucellosis and the British Tourist

Industry

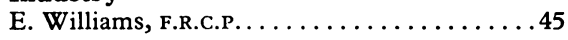

Ketamine Anaesthesia

J. W. Dundee, F.F.A. R.C.S., and J. Moore,

F.F.A. R.C.S.; H. R. W. Lunt, M.CH.ORTH.; J. P.

Alexander, F.F.A. R.C.S.; D. L. Coppel, F.F.A.

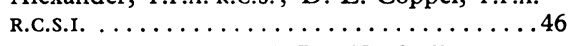

Fractured Femur and Fat Embolism

P. A. Ring, F.R.C.s.; N. H. Harris, F.R.C.S. . . .46

Accidental Poisoning with Malathion

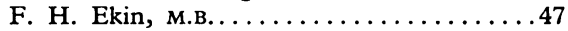

Penicillin and the Mouth Flora

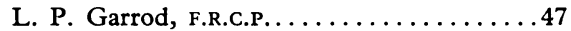

Management of Malignant Disease

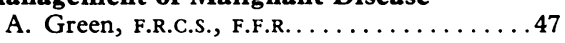

Dermatoglyphics and Chromosomes in Cat-eye Syndrome

C. W. Darby, M.R.C.P., and D. T. Hughes,

PH.D. . . . . . . . . . . . . . . . 47

Ampicillin and Mononucleosis

I. J. Nazareth, M.D..............48

Pulmonary Gas Exchange during Dialysis

S. Freedman, PH.D., M.R.C.P., and D. J.

Maberly, M.R.C.P.............48

Dental Discolouration and Tetracycline

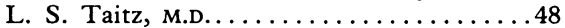

Cure of Lung Cancer after Incomplete

Surgical Resection

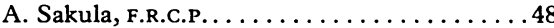

Acid-base Balance and Bleeding

T. C. Northfield, M.R.C.P., and others . . . . . . 49

Myocardial Infarction and the G.P.

J. H. Horgan, M.R.C.P.I............49

Suicide and Euthanasia

D. A. Roche, M. B............. 50
X-ray Equipment

D. J. Manton, D.M.R.D...........50

Logical Foundations of Medicine

W. C. Watson, M.D. . . . . . . . . . . . . 50

Child Health in a Changing Community

Muriel J. Brayshay, M.B...........51

Health of Young People

S. E. Ellison, M.B., D.C.H. . . . . . . . . 51

Failure to Continue Education

E. D. Sever, M.R.C.P., and others. . . . . . 51

False Economy

C. J. Day, M.в...............51

Coroner's Power to Commit for Trial

H. H. Pilling, M.B............. 51

Functions of the G.M.C.

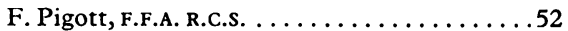

Hospital Staffing Structure

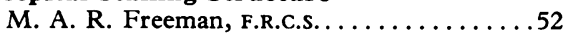

Temporary Resident Fees

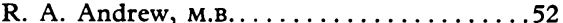

Vocational Training for General Practice

D. J. G. Bain, M.B., D.C.H...........53

\section{The Managerial Revolution}

SIR,-May I, as one of the present health service mangers, add to the plea, expressed by all five of the correspondents on the subject (12 June, p. 648), for a close scrutiny of the Consultative Document on the $\mathrm{Re}$ organization of the Health Service? ${ }^{1}$

There is not much time, as the legislation is already being drafted, and much needs to be done if valid opinions are to be expressed by the end of July.

Mr. R. Murley wisely questions the need to dispense with the present tripartite system, but if we must have a new system then let us understand that the one proposed will depend on decision making at four levels.

(1) The Department of Health and Social Services-much as at present.

(2) The regional health authority, responsible for planning and allocating funds (with a special committee concerned with the service aspects of teaching and research) and employing consultant staff.

(3) The area health authority, intended to be the operational body-that is, to run the hospitals and the other branches of the service. These services would be divided into "districts," but in general there would be only officers to run the districts, not committees.

(4) In a teaching district, the district committee, undertaking local management and holding teaching hospital endowment funds.

In the non-teaching areas, of which there are to be 70 or 80 outside London, a board of 15 persons will have to run, through its officers, an average of some $\mathbf{3 5}$ hospitals, this being three or four times the size of the present groups, plus the general practitioner service, plus the present local authority health services, with a budget of some $£ 20 \mathrm{~m}$. and a staff of some 10,000 . It will need a lot of officers-the document rightly refers to thousands.

In the teaching districts decisions on different subjects will be made at any of the four levels. The universities and London medical schools must be wondering with whom they will deal in future. It is difficult to see how the teaching hospital can remain as a cohesive, effective whole.

I write from a teaching hospital with nearly 1,800 beds serving a population of 270,000 people, $95 \%$ of the inpatients coming from the allotted catchment area or the immediate surroundings. I use the words "effective" and "serving" in the belief that a reasonably effective service is provided to the public, as well as to the medical school, but experience makes me conclude that a group substantially larger would be much less effective. I think that the concept of an "area" of the proposed size as the effective decision making body should be re-examined in this light.

I believe that the medical profession should look carefully into the medical content of the much reduced membership of governing bodies, into the expected number and quality of the non-medical managerial staff the new system will need, into the channels of communication of medical opinion on management matters, into the number of places in which decisions affecting doctors will be made, and into the service to medical education that will be provided. They will find more bureaucracy than they will like, and as a bureaucrat I am against bureaucracy on this scale.-I am, etc.,

J. D. BANKS

London S.E.1

House Governor,

1 Department of Health and Social Security, National Health Service Reorganization: Consultative Document, 1971.

SIR,-Already in your columns we see stirring doubts of the profession about the proposed managerial revolution (12 June, p. 648,19 June, p. 714). The new consultative document $^{1}$ was recently considered by the Kettering Division of the B.M.A., and the purpose of this letter is to increase the present stirring to a general swell of discussion. The document is totally inadequate as a final basis for discussion and leaves much that needs debate, yet undebated, for this very reason.

Apart from points of detail, this Division feels strongly that the Government is pressing ahead too quickly with a programme which smacks of reform for reform's sake. Certainly there is much to be done to improve the administrative framework of the National Health Service, but we doubt that in order to attain this, it is necessary to introduce the new concept of the area health authority. Why can we not reorganize and integrate from within the present structure? The existing regional hospital boards could become regional health authorities as suggested in the paper, and could assume overall planning responsibilities for a number of 